\title{
PLUNC: a multifunctional surfactant of the airways
}

\author{
Jennifer Bartlett ${ }^{\star}$, Lokesh Gakhar ${ }^{\dagger}$, Jon Penterman $\ddagger, \S$, Pradeep Singh ${ }^{\ddagger}$, , Rama K. \\ Mallampallill, Edith Porter", and Paul B. McCray Jr ${ }^{*}, 1$ \\ "Department of Pediatrics, University of lowa Carver College of Medicine, 240 EMRB, lowa City, \\ IA 52242, U.S.A \\ tDepartment of Biochemistry and Protein Crystallography Facility, University of lowa Carver \\ College of Medicine, 240 EMRB, lowa City, IA 52242, U.S.A \\ ‡Department of Microbiology, University of Washington, Seattle, WA 98195, U.S.A \\ $\S$ Department of Medicine, University of Washington, Seattle, WA 98195, U.S.A \\ "Department of Medicine, University of Pittsburgh, Pittsburgh, PA 15261, U.S.A \\ IDepartment of Biological Sciences, California State University, Los Angeles, CA 90032, U.S.A
}

\section{Abstract}

PLUNC (palate, lung and nasal epithelium clone) protein is an abundant secretory product of epithelia throughout the mammalian conducting airways. Despite its homology with the innate immune defence molecules BPI (bactericidal/permeability-increasing protein) and LBP (lipopolysaccharide-binding protein), it has been difficult to define the functions of PLUNC. Based on its marked hydrophobicity and expression pattern, we hypothesized that PLUNC is an airway surfactant. We found that purified recombinant human PLUNC exhibited potent surfactant activity by several different measures, and experiments with airway epithelial cell lines and primary cultures indicate that native PLUNC makes a significant contribution to the overall surface tension in airway epithelial secretions. Interestingly, we also found that physiologically relevant concentrations of PLUNC-inhibited Pseudomonas aeruginosa biofilm formation in vitro without acting directly as a bactericide. This finding suggests that PLUNC protein may inhibit biofilm formation by airway pathogens, perhaps through its dispersant properties. Our data, along with reports from other groups on activity against some airway pathogens, expand on an emerging picture of PLUNC as a multifunctional protein, which plays a novel role in airway defences at the air/liquid interface.

\section{Keywords}

biofilm; conducting airway; innate immunity; palate; lung and nasal epithelium clone (PLUNC); surfactant

\section{Introduction}

The conducting airways are regularly exposed to an array of microbes and other particulates through breathing and micro-aspiration. It is therefore important to understand the mechanisms by which conducting airway epithelia and their products protect the host from infection and/or colonization by invading micro-organisms. The airway surface and

\footnotetext{
(C)2011 Biochemical Soceity

${ }^{1}$ To whom correspondence should be addressed (paulmccray@uiowa.edu).
} 
submucosal gland epithelium serves as a vital barrier separating microbial invaders from underlying tissues, while the co-ordinated beating of cilia facilitates clearance of bacteria, viruses and other particles in the process of mucociliary clearance. Additionally, the conducting airways are bathed in a layer of fluid known as ASL (airway surface liquid), which contains many factors co-operating to prevent potential pathogens from getting a foothold in the lung. ASL contains a number of secreted innate immune molecules with defined host defence roles, including classical antimicrobial proteins and peptides such as lysozyme, lactoferrin, the defensins and LL37 [1,2]. In addition, airway secretions contain many factors that contribute to other aspects of host defence or to ASL homoeostasis, such as mucins, electrolytes and surfactants.

The identity and function of surfactants within the ASL of the conducting airways are a particularly poorly understood aspect of airway innate immunity. Even though, like the alveolar airspaces, it has been recognized for some years that the conducting airways also possess some form of surface-active material [3-6], it has been unclear which molecule(s) are responsible for this surface activity. In alveolar surfactant, surface tension lowering is brought about by a potent mix of lipids and the lipid-binding proteins SP-B (surfactant protein B) and SP-C (surfactant protein C). While conducting airway secretions contain many of the same lipid species found in alveolar surfactant, the surfactant proteins SP-B and SP-C are notably absent in ASL [3,7], suggesting that a unique protein (or group of proteins) is probably involved in surface tension reduction in the upper respiratory tract. A further mystery revolves around the question of why an upper airway surfactant is necessary at all. In the parenchyma, pulmonary surfactant provides mechanical advantages, promoting lung compliance and helping to prevent alveolar collapse during respiration. In the upper respiratory tract, however, airway structures are supported by cartilage, making airway collapse less likely. It has therefore been unclear as to what benefit a surfactant might provide in this region.

\section{PLUNC (palate, lung and nasal epithelial clone): an abundant protein in airway secretions}

Among the most abundant products in airway secretions is the PLUNC protein. PLUNC [also known as SPLUNC1 (short PLUNC 1), LUNX (lung-specific X protein), NASG (nasopharyngeal carcinoma-related protein) or SPURT (secretory protein in upper respiratory tracts)] is a secreted glycoprotein of approximately $25 \mathrm{kDa}$ that is highly expressed throughout the upper respiratory tract and whose function is only emerging. In the trachea and bronchus, PLUNC is secreted by surface epithelia as well as the submucosal glands [8]. PLUNC protein has been identified in nasal lavage fluid [9], saliva [10,11] and tracheal aspirates [8], and is also abundant in secretions from cultured airway epithelia $[8,10]$. We estimate that, in secretions from primary cultures of human airway epithelia, PLUNC concentrations are in the range 10-250 $\mu \mathrm{g} / \mathrm{ml}[12]$.

PLUNC belongs to a larger family of related proteins, whose genes reside in a 300-kb region on human chromosome 20 [13]. Together, this group of PLUNC-related proteins comprise a branch of the LT (lipid transfer)/LBP [LPS (lipopolysaccharide)-binding protein] family, whose other members include the innate immune molecules BPI (bactericidal/permeabilityincreasing protein) and the LBP, as well as the serum glycoproteins CETP (cholesteryl estertransfer protein) and PLTP (phospholipid-transfer protein). A defining feature of the LT/ LBP protein family is a propensity for binding lipid substrates. In the case of BPI and LBP, the preferred lipid substrate appears to be the lipid A moiety of LPS found in the Gramnegative bacterial cell wall. Through their interactions with bacterial LPS, BPI and LBP participate in multiple aspects of sensing and responding to Gram-negative bacteria, including modulation of LPS-induced inflammation [14]. Additionally, BPI is directly 
antimicrobial against Gram-negative micro-organisms [15]. The other two LT/LBP family members, CETP and PLTP, are circulating proteins primarily involved in transfer and exchange of host-derived lipids between plasma lipoproteins $[16,17]$.

Based largely on its evolutionary relationship to BPI and LBP, the PLUNC protein is generally conceived as a host defence molecule whose activities are specially adapted for the conducting airways. This idea is supported by its distribution in the respiratory tract, at sites of frequent microbial exposure. Supporting this hypothesis, there are hints of a connection between PLUNC and inflammation, as investigators have documented that PLUNC levels are altered in response to olfactory bulbectomy [18], seasonal allergic rhinitis [19] and airway insults such as smoking [20] and chemical irritants [21]. However, direct evidence for antimicrobial activity by PLUNC is limited. In experiments with recombinant PLUNC protein, our group has failed to detect antimicrobial activity against $P$ seudomonas aeruginosa, Escherichia coli or Listeria monocytogenes [22]. Chu et al. [23] also reported minimal killing of E. coli, but did observe significant growth inhibition of Mycoplasma pneumoniae. On the other hand, McGillivary and Bakaletz [24] reported that native PLUNC protein isolated from chinchilla nasopharyngeal epithelia has direct antimicrobial activity against NTHi (non-typeable Haemophilus influenzae). To date, it appears that, unlike many of the more traditional innate immune molecules, PLUNC does not possess obvious broadspectrum bactericidal activity and may instead target only specific airway pathogens. Furthermore, this led us to consider the possibility that PLUNC may additionally contribute to host defence in some previously unknown ways.

\section{PLUNC as an airway surfactant}

We and others have noted primary protein sequence similarity between PLUNC and the equine protein latherin $[12,25,26]$. Latherin, originally isolated from horse sweat and subsequently shown to be present in saliva as well, exerts potent surfactant effects at air/ liquid interfaces [26-28]. Latherin is a member of the equine PLUNC cluster, and shares an interesting property with the human PLUNC protein in that it exhibits an unusually high degree of hydrophobicity. As shown in Table 1, hydrophobic residues make up a similar proportion of the total amino acid content in latherin and PLUNC (44.2\% in latherin, 44.7 $\%$ in PLUNC), on the upper end of what is observed for other members of the PLUNC family. More notable, however, is the observation that, for both proteins, this hydrophobicity arises from enrichment in leucine residues, a property that appears to be unique to these two family members. The marked hydrophobicity of these two proteins suggests obvious comparisons with the critical surfactant proteins SP-B and SP-C in alveolar surfactant, whose active forms are also remarkably hydrophobic (Table 1 ).

Given these observations, we asked whether PLUNC might play a surfactant-like role in upper airway fluids. We first tested recombinant PLUNC protein for surfactant activity, using a variety of in vitro assays. In contact angle studies, we examined the spreading behaviour of aqueous solutions on a solid hydrophobic surface. We found that drops of PLUNC-containing solutions exhibited significantly reduced advancing contact angles relative to drops containing buffer alone or control proteins [12], a finding which suggests that spreading is enhanced in the presence of PLUNC protein. Such a result is consistent with the expected behaviour for a surfactant. To test for surfactant activity at air/liquid interfaces, arguably a more biologically relevant setting, we used the pulsating bubble surfactometer to directly measure surface tension in solutions containing PLUNC across a range of physiological concentrations (Figure 1). We found that recombinant PLUNC protein reduced surface tension in a dose-dependent manner in these solutions, to a minimum value of $\sim 18 \mathrm{mN} / \mathrm{m}$. The surface tension lowering effects were observed at concentrations as low as $1-2 \mu \mathrm{g} / \mathrm{ml}$; concentrations of only $10 \mu \mathrm{g} / \mathrm{ml}$ were required for 
maximal activity. In terms of effectiveness as a surfactant, our results suggest that PLUNC falls somewhere between the activity that would be observed for a non-surfactant protein such as BSA, which has no, or only a very modest, effect on surface tension even at high concentrations, and Infasurf, a commercial pulmonary surfactant preparation used to treat infants with respiratory distress syndrome, which can achieve surface tensions approaching $0 \mathrm{mN} / \mathrm{m}$ [12]. Recently, we have measured surface tension in washings from air/liquid interface primary cultures of well-differentiated human airway epithelia, which normally express and secrete PLUNC protein. Interestingly, surface tensions in these washes typically range from 20 to $35 \mathrm{mN} / \mathrm{m}$, consistent with published values for in vivo surface tension measured in the trachea and bronchi of large mammals [5,6], and also well within a range achieved with purified PLUNC (based on our in vitro studies). These observations suggest that the surfactant-like properties we have detected with recombinant, purified PLUNC are probably retained by native PLUNC protein produced in the mammalian airways.

\section{A possible role in anti-biofilm defence}

As noted above, the biological role of surfactant(s) in the conducting airways is not well understood, but is likely to be distinct from that of alveolar surfactant. There is growing recognition that surfactants can disrupt or prevent formation of biofilms, which are surfaceattached communities of bacteria growing within a matrix that provides protection against environmental challenges such as host immune defences. To date, much of the literature on this topic has focused on secretion of surfactants by microbes as a means to prevent biofilm formation by competing microbes [29,30], or to escape from their own biofilms during the detachment stage of the biofilm lifestyle $[31,32]$.

We hypothesized that mammals may similarly produce surfactants as a strategy to combat bacterial colonization in the airways. To test this idea, we assessed the effects of recombinant PLUNC on biofilm formation by the opportunistic pathogen Ps. aeruginosa. In an in vitro model of biofilm formation, PS. aeruginosa cultures were grown overnight in static conditions, resulting in the formation of a biofilm structure at the air/liquid interface, known as a pellicle. We found that pellicle formation was significantly diminished (although not completely prevented) when bacteria were cultured in the presence of recombinant PLUNC [12], suggesting that PLUNC has the capacity to inhibit biofilm formation under these culture conditions (Figure 2). It is important to point out that PLUNC was not significantly bactericidal against $P$ s. aeruginosa in earlier antimicrobial studies [22], and thus we conclude that the reduced pellicle in this assay was not due to direct killing of the bacteria, but instead due to PLUNC interference with some step in biofilm development. Based on this finding, we suggest that, in addition to its possible antimicrobial effects against particular microbes, PLUNC may further contribute to airway innate immunity by reducing surface tension at the bacteria/matrix interface or the bacterial/bacterial interface, thereby interfering with early steps in biofilm establishment such as bacterial aggregation or microcolony formation. This in turn may maintain infecting bacteria in a non-aggregated state that is more susceptible to other host defence factors.

\section{Future directions}

Our findings indicate that PLUNC represents a previously unrecognized surfactant in the conducting airways of mammals. This lowering of surface tension at the mucosal surface may represent a novel form of innate immunity that limits bacterial colonization of the airways. A number of critical questions remain to be explored. Most importantly, studies in a Plunc-deficient animal model will be required to address the in vivo relevance of these observations. It will also be important to more clearly define the mechanism by which PLUNC inhibits biofilm formation, by performing experiments designed to determine the 
stages of biofilm formation at which PLUNC exerts its effects, and to explore interaction with other defence molecules. Perhaps the abundance or function of PLUNC in respiratory secretions influences the normal commensal microbiota. Another question regarding the innate immune properties of PLUNC is whether the protein shares the lipid-binding properties of other LT/LBP family members. For example, does PLUNC interact with host and/or microbial lipids? Future studies of the multifunctional PLUNC protein may reveal previously unappreciated aspects of innate immunity in the conducting airways.

\section{Acknowledgments}

Funding

We acknowledge support from National Institutes of Health [grant number P50 HL-61234 and P01 HL-091842], as well as the Roy J. Carver Charitable Trust. In addition, this work was funded by the National Institute for Environmental Health Sciences Research Centre [grant number NIEHS/NIH P30 ES05605].

\section{Abbreviations used}

$\begin{array}{ll}\text { ASL } & \text { airway surface liquid } \\ \text { BPI } & \text { bactericidal/permeability-increasing protein } \\ \text { CETP } & \text { cholesteryl ester-transfer protein } \\ \text { GRAVY } & \text { grand average of hydropathy } \\ \text { LPS } & \text { lipopolysaccharide } \\ \text { LBP } & \text { LPS-binding protein } \\ \text { LT } & \text { lipid transfer } \\ \text { PLTP } & \text { phospholipid-transfer protein } \\ \text { PLUNC } & \text { palate, lung and nasal epithelium clone } \\ \text { SP-B } & \text { surfactant protein B } \\ \text { SP-C } & \text { surfactant protein C } \\ \text { SPLUNC1 } & \text { short PLUNC 1 }\end{array}$

\section{References}

1. Bartlett JA, Fischer AJ, McCray PB Jr. Innate immune functions of the airway epithelium. Contrib Microbiol. 2008; 15:147-163. [PubMed: 18511860]

2. Ganz T. Antimicrobial polypeptides. J Leukocyte Biol. 2004; 75:34-38. [PubMed: 12960278]

3. Bernhard W, Haagsman HP, Tschernig T, Poets CF, Postle AD, van Eijk ME, von der Hardt H. Conductive airway surfactant: surface-tension function, biochemical composition, and possible alveolar origin. Am J Respir Cell Mol Biol. 1997; 17:41-50. [PubMed: 9224208]

4. Gil J, Weibel ER. Extracellular lining of bronchioles after perfusion-fixation of rat lungs for electron microscopy. Anat Rec. 1971; 169:185-199. [PubMed: 5544617]

5. Im Hof V, Gehr P, Gerber V, Lee MM, Schurch S. In vivo determination of surface tension in the horse trachea and in vitro model studies. Respir Physiol. 1997; 109:81-93. [PubMed: 9271810]

6. Schurch S, Gehr P, Im Hof V, Geiser M, Green F. Surfactant displaces particles toward the epithelium in airways and alveoli. Respir Physiol. 1990; 80:17-32. [PubMed: 2367749]

7. Khoor A, Stahlman MT, Gray ME, Whitsett JA. Temporal-spatial distribution of SP-B and SP-C proteins and mRNAs in developing respiratory epithelium of human lung. J Histochem Cytochem. 1994; 42:1187-1199. [PubMed: 8064126] 
8. Campos MA, Abreu AR, Nlend MC, Cobas MA, Conner GE, Whitney PL. Purification and characterization of PLUNC from human tracheobronchial secretions. Am J Respir Cell Mol Biol. 2004; 30:184-192. [PubMed: 12920053]

9. Lindahl M, Stahlbom B, Tagesson C. Identification of a new potential airway irritation marker, palate lung nasal epithelial clone protein, in human nasal lavage fluid with two-dimensional electrophoresis and matrix-assisted laser desorption/ionization-time of flight. Electrophoresis. 2001; 22:1795-1800. [PubMed: 11425234]

10. Di YP, Harper R, Zhao Y, Pahlavan N, Finkbeiner W, Wu R. Molecular cloning and characterization of SPURT, a human novel gene that is retinoic acid-inducible and encodes a secretory protein specific in upper respiratory tracts. J Biol Chem. 2003; 278:1165-1173. [PubMed: 12409287]

11. Vitorino R, Lobo MJ, Ferrer-Correira AJ, Dubin JR, Tomer KB, Domingues PM, Amado FM. Identification of human whole saliva protein components using proteomics. Proteomics. 2004; 4:1109-1115. [PubMed: 15048992]

12. Gakhar L, Bartlett JA, Penterman J, Mizrachi D, Singh PK, Mallampalli RK, Ramaswamy S, McCray PB Jr. PLUNC is a novel airway surfactant protein with anti-biofilm activity. PLoS ONE. 2010; 5:e9098. [PubMed: 20161732]

13. Bingle CD, Craven CJ. PLUNC: a novel family of candidate host defence proteins expressed in the upper airways and nasopharynx. Hum Mol Genet. 2002; 11:937-943. [PubMed: 11971875]

14. Weiss J. Bactericidal/permeability-increasing protein (BPI) and lipopolysaccharide-binding protein (LBP): structure, function and regulation in host defence against Gram-negative bacteria. Biochem Soc Trans. 2003; 31:785-790. [PubMed: 12887306]

15. Weiss J, Elsbach P, Olsson I, Odeberg H. Purification and characterization of a potent bactericidal and membrane active protein from the granules of human polymorphonuclear leukocytes. J Biol Chem. 1978; 253:2664-2672. [PubMed: 344320]

16. Tollefson JH, Ravnik S, Albers JJ. Isolation and characterization of a phospholipid transfer protein (LTP-II) from human plasma. J Lipid Res. 1988; 29:1593-1602. [PubMed: 2854151]

17. Yamashita S, Hirano K, Sakai N, Matsuzawa Y. Molecular biology and pathophysiological aspects of plasma cholesteryl ester transfer protein. Biochim Biophys Acta. 2000; 1529:257-275. [PubMed: 11111094]

18. Sung YK, Moon C, Yoo JY, Pearse D, Pevsner J, Ronnett GV. Plunc, a member of the secretory gland protein family, is up-regulated in nasal respiratory epithelium after olfactory bulbectomy. $\mathrm{J}$ Biol Chem. 2002; 277:12762-12769. [PubMed: 11821380]

19. Ghafouri B, Irander K, Lindbom J, Tagesson C, Lindahl M. Comparative proteomics of nasal fluid in seasonal allergic rhinitis. J Proteome Res. 2006; 5:330-338. [PubMed: 16457599]

20. Ghafouri B, Stahlbom B, Tagesson C, Lindahl M. Newly identified proteins in human nasal lavage fluid from non-smokers and smokers using two-dimensional gel electrophoresis and peptide mass fingerprinting. Proteomics. 2002; 2:112-120. [PubMed: 11788998]

21. Ghafouri B, Kihlstrom E, Stahlbom B, Tagesson C, Lindahl M. PLUNC (palate, lung and nasal epithelial clone) proteins in human nasal lavage fluid. Biochem Soc Trans. 2003; 31:810-814. [PubMed: 12887311]

22. Bartlett JA, Hicks BJ, Schlomann JM, Ramachandran S, Nauseef WM, McCray PB Jr. PLUNC is a secreted product of neutrophil granules. J Leukocyte Biol. 2008; 83:1201-1206. [PubMed: 18245229]

23. Chu HW, Thaikoottathil J, Rino JG, Zhang G, Wu Q, Moss T, Refaeli Y, Bowler R, Wenzel SE, Chen Z, et al. Function and regulation of SPLUNC1 protein in Mycoplasma infection and allergic inflammation. J Immunol. 2007; 179:3995-4002. [PubMed: 17785838]

24. McGillivary G, Bakaletz LO. The multifunctional host defense peptide SPLUNC1 is critical for homeostasis of the mammalian upper airway. PLoS ONE. 2010; 5:e13224. [PubMed: 20949060]

25. Bingle CD, LeClair EE, Havard S, Bingle L, Gillingham P, Craven CJ. Phylogenetic and evolutionary analysis of the PLUNC gene family. Protein Sci. 2004; 13:422-430. [PubMed: 14739326] 
26. McDonald RE, Fleming RI, Beeley JG, Bovell DL, Lu JR, Zhao X, Cooper A, Kennedy MW. Latherin: a surfactant protein of horse sweat and saliva. PLoS ONE. 2009; 4:e5726. [PubMed: 19478940]

27. Beeley JG, Eason R, Snow DH. Isolation and characterization of latherin, a surface-active protein from horse sweat. Biochem J. 1986; 235:645-650. [PubMed: 3753435]

28. Goubran Botros H, Poncet P, Rabillon J, Fontaine T, Laval JM, David B. Biochemical characterization and surfactant properties of horse allergens. Eur J Biochem. 2001; 268:31263136. [PubMed: 11358533]

29. Irie Y, O’Toole GA, Yuk MH. Pseudomonas aeruginosa rhamnolipids disperse Bordetella bronchiseptica biofilms. FEMS Microbiol Lett. 2005; 250:237-243. [PubMed: 16098688]

30. Walencka E, Rozalska S, Sadowska B, Rozalska B. The influence of Lactobacillus acidophilusderived surfactants on staphylococcal adhesion and biofilm formation. Folia Microbiol. 2008; 53:61-66. [PubMed: 18481220]

31. Boles BR, Thoendel M, Singh PK. Rhamnolipids mediate detachment of Pseudomonas aeruginosa from biofilms. Mol Microbiol. 2005; 57:1210-1223. [PubMed: 16101996]

32. Pamp SJ, Tolker-Nielsen T. Multiple roles of biosurfactants in structural biofilm development by Pseudomonas aeruginosa. J Bacteriol. 2007; 189:2531-2539. [PubMed: 17220224]

33. Weaver TE, Conkright JJ. Function of surfactant proteins B and C. Annu Rev Physiol. 2001; 63:555-578. [PubMed: 11181967]

34. Kyte J, Doolittle RF. A simple method for displaying the hydropathic character of a protein. J Mol Biol. 1982; 157:105-132. [PubMed: 7108955] 


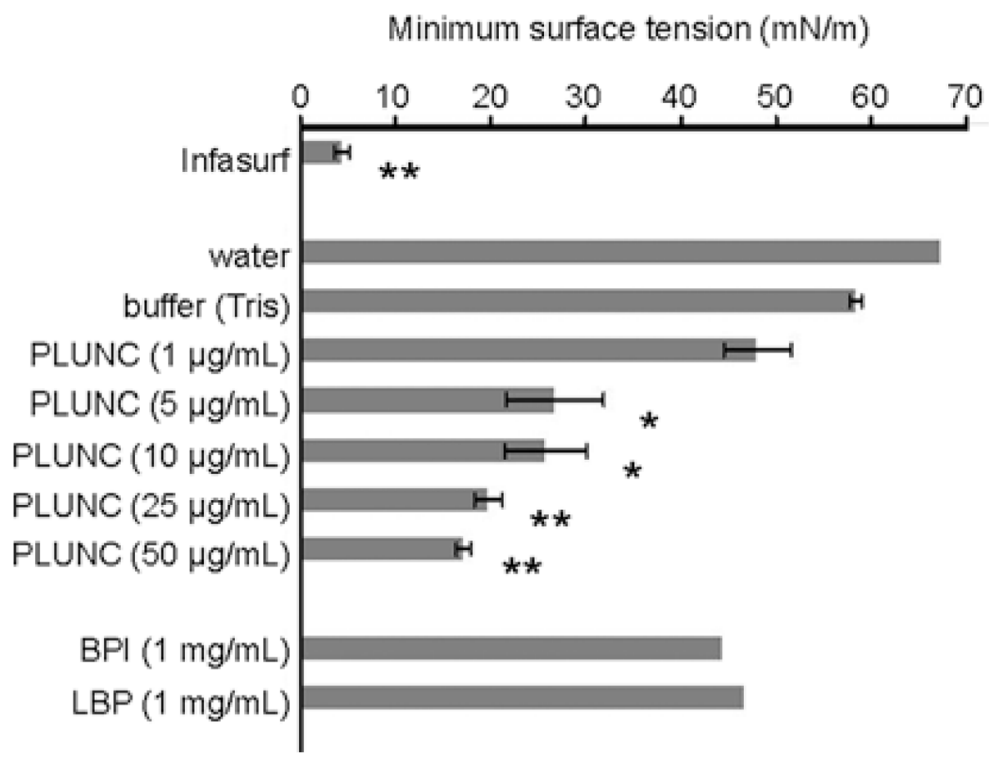

Figure 1. PLUNC potently reduces surface tension at the air/liquid interface

Dynamic surface tension was measured for various solutions using the pulsating bubble surfactometer. Grey bars represent the mean minimum surface tension achieved after 5 min of pulsation. Results are means \pm S.E.M. Asterisks indicate samples that exhibited statistically significant reductions in surface tension relative to the buffer control, as determined by Student's $t$ test $(* P<0.01$; $* * P<0.0001)$. 


\section{untreated PLUNC buffer}
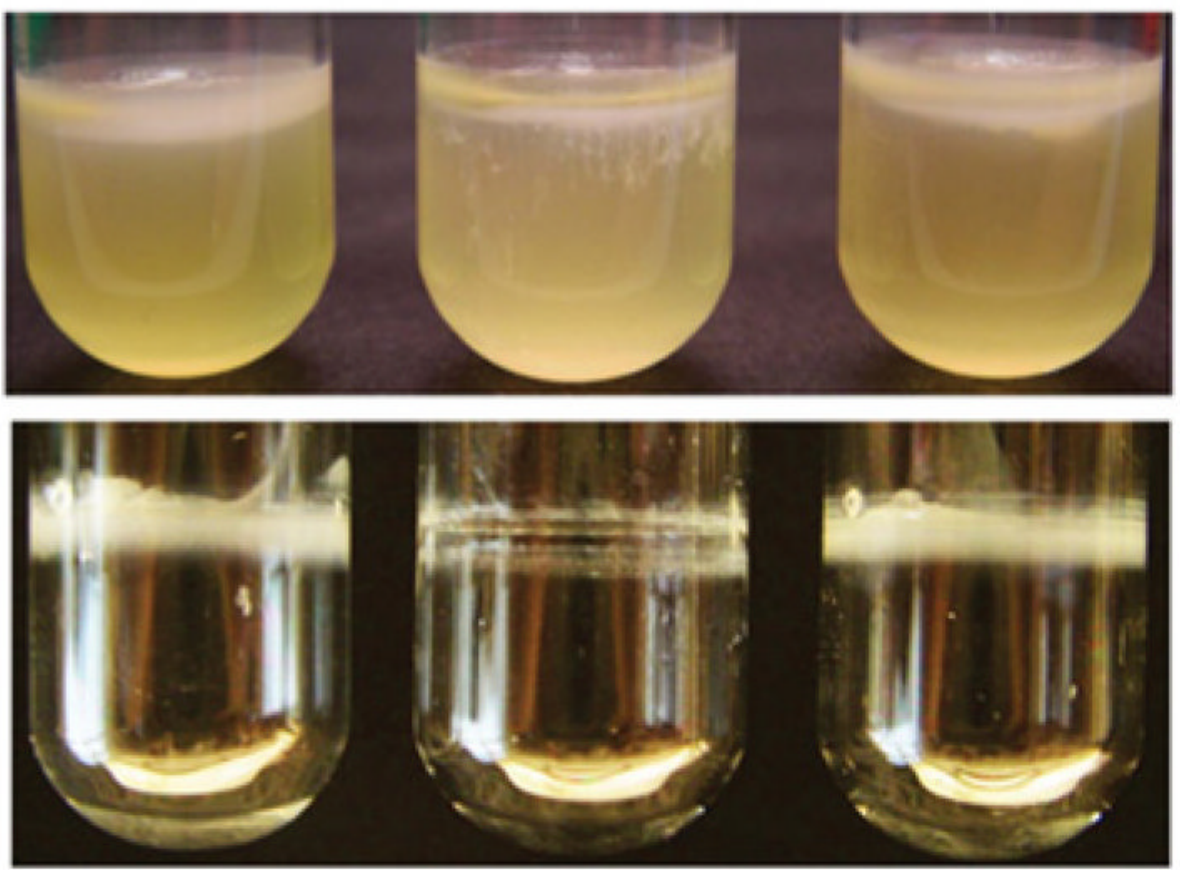

Figure 2. PLUNC inhibits Ps. aeruginosa biofilm formation at the air/liquid interface in vitro Upper panel: static broth cultures of PS. aeruginosa PA14 were grown for $48 \mathrm{~h}$, producing biofilms (pellicles) at the air/liquid interface. In contrast with the untreated and buffertreated cultures, bacteria grown in the presence of PLUNC $(100 \mu \mathrm{g} / \mathrm{ml})$ exhibited significantly decreased pellicle formation in this assay. Lower panel: following the removal of medium, PLUNC-treated cultures exhibited reduced biomass adhering to the sides of culture tubes after $72 \mathrm{~h}$ of growth. 
Table 1

Hydrophobicity of selected LT/LBP family members

Amino acid sequences for horse latherin, BPI and LBP, as well as the PLUNC family members BASE (breast cancer and salivary gland-expressed) protein, PLUNC (also known as SPLUNC1), SPLUNC2 and SPLUNC3, are available through the NCBI (National Center for Biotechnology Information) website (http://

www.ncbi.nlm.nih.gov). The analyses for SP-B and SP-C are based on their mature proteolytically processed peptide forms [33]. In this analysis, the amino acids isoleucine, valine, leucine, phenylalanine, cysteine, methionine and alanine are considered to be the hydrophobic residues, according to the hydropathy index developed by Kyte and Doolittle [34]. The GRAVY (grand average of hydropathicity) value is calculated by summing the hydropathy values for each amino acid in a protein and dividing by the total number of residues. Hydrophobic proteins produce calculated GRAVY values $>0$, whereas hydrophilic proteins will exhibit GRAVY $<$.

\begin{tabular}{lllll}
\hline Protein & NCBI accession no. & Total hydrophobic residues $(\%)$ & Leucine composition $(\%)$ & GRAVY \\
\hline Latherin & NP_001075328 & 44.2 & 23.6 & 0.330 \\
hBASE & AAO17728.1 & 40.3 & 15.7 & 0.040 \\
hPLUNC & NP_057667 & 44.7 & 23.2 & 0.563 \\
hSPLUNC2 & NP_542141 & 41.6 & 16.0 & 0.113 \\
hSPLUNC3 & NP_848561.2 & 38.2 & 9.9 & -0.308 \\
BPI & NP_001716.2 & 39.1 & 10.3 & -0.075 \\
LBP & NP_004130.2 & 40.4 & 13.8 & -0.002 \\
SP-B & N/A & 60.8 & 17.7 & 1.027 \\
SP-C & N/A & 77.1 & 20.0 & 2.466 \\
\hline
\end{tabular}

